\title{
Impact of Construction Project Execution with and without Project Management Software
}

\author{
V. Subburaj, Ramesh Babu Chokkalingam, M. Shanmugasundaram
}

\begin{abstract}
The delay of work is common in construction projects. Delay has a major impact on time and cost overrun. Project management helps to avoid or minimize delays in future work. Here in this paper, two private residential apartments are considered for evaluation. One project has been executed using software and the second project has no such process. The first project prepared with time schedule, resource allocation and levelling, estimation, billing and cash flow all the details using the software tools helps to execute the project with more profit and less delay in work execution whereas the other experimental project is not having plan, same less resource, poor execution leads to heavy loss and more stress to the builder.
\end{abstract}

Keywords : Analytical methods, Production models, Theoretical framework, Construction management.

\section{INTRODUCTION}

Tamil Nadu has seen high growth in construction activity of all types, residential and commercial. It has been noted that only $30 \%$ of the construction projects were completed within the scheduled completion dates and that the average time overrun was between $10 \%$ and $30 \%$. The construction industry faces on-going challenges both externally and internally. From an internal view point the increase in the number of features in a project scope, against shorter construction deadlines and restricted budgets raise the complexity of the building construction projects. We may adopt any technology for construction of a project, but completion of work on time and within the budgeted cost is a big issue faced by construction industries. But in our experimental projects one project completed as per schedule using various project management tools and one project get delays of around nearly 10 times the actual duration, which clearly shows the major loss on the project having poor quality engineers and improper supervision with less knowledge on building construction. The main objective is to get more profit and gain in time in a project using software tools is a must, also it releases more stress and strain to the contractor, client as well as the labours. Yu Maemura, Ph.D.et al. (2018)have identified contractual conflicts as a major cause of construction delays in international construction projects, their underlying causes have been rarely explored.

Revised Manuscript Received on December 5, 2019

* Correspondence Author

V.Subburaj*, Department of Civil Engineering, PSNACET, Dindigul, Tamilnadu, India. subburajroja@gmail.com

Ramesh Babu Chokalingam, Department of Civil Engineering,Kalasalingam University, Tamilnadu, India. babussr@gmail.com

M.Shanmugasundaram, School of Mechanical and Building sciences, VIT-Chennai Campus, Tamilnadu, India, shamugaresearch@gmail.com

Connie Tenin Su; et al. (2108) proposes a deterministic and a probabilistic constructive heuristic for solving the project scheduling resource availability cost problem with tardiness
(RACPT), as well as a new mixed integer mathematical formulation with disjunctive constraints and time modeled as a continuous variable. Mei-yung Leung, et al. (2017) investigated the interactions among stressors, stress, performance, and intention to stay for expatriate construction professionals (ExCPs) through the development of a stress.

\section{IMPORTANCE OF THE STUDY}

Conflicts arises between parties (owner, contractor and/or third party), in regards ${ }^{\text {ee }}$ to file claims for extra compensation or extra time to complete a project. To recover the damages caused by delays, the parties responsible for the occurrence should be identified.

\section{PROJECT 1}

SOFTWARE USED:AutoCAD, Primavera, MS Project, and Microsoft Excel.

\section{LOCATION STUDY}

Location : Subhamnagar,Mahaveersalai, J.Pallavaram,Chennai-117.

Proposed Area : 1393.55 Sq.m

Type of terrain : Plain Terrain

Type of Building : Apartments - Residential tower.

Type of soil : Foundation lies on softy disintegrated rock.

SBC : 36 tonnes/ Sq.m

Type of Footing : Isolated Column footing.

\section{A. PLANNING AND SCHEDULING}

For this scheduling process Primavera software is used. In this software, the Organizational Breakdown Structure (OBS) that represents the organisation. The Enterprise Project Structure (EPS) represents how the project is organized. The OBS and EPS are combined together through the responsible manager field on the EPS structure. The responsible manager field is the OBS and this determines what users can gain access to the project. The EPS is further divided into number of work breakdown structure(WBS). After certain the WBS, the activities are created. For those activities, the required resources are assigned.

\section{B. RESOURCE MANAGEMENT}

Resource management is the utilization of resources in a planned manner by allocating and leveling them in different tasks with a good model tool implementing leveling using graph. 


\section{- Resource Allocation}

Resource allocation with the help of can be done for Men, Materials and Machineries. The below mentioned schedule shows some of the samples for resource details obtained from primavera software tools. The following are some of the tables (samples) for resource details obtained from the Primavera software,

\section{- Resource Levelling}

Resource levelling is a process in which the finish date of the project can be as per the availability of the resources. But, by running the primavera and level checker resource levelling can be done in this project it level the resources within the activity.Over allocation done on the project by levelling and without altering the finish date. The following are some of the sample results of leveled resources obtained from the Primavera software.

\section{- Budgeting}

Budgeting can be framed only by using cost estimation. This budget details clearly shows how the funds can be utilized over time for projects.Budget clearly gives the amount to be spend over a particular period of time, it also include outline plan for money spend and breakdown, Accurate budget will give a better result on how to plan the resources as per schedule and various types of work required to complete the tasks.It also exposes cost constraint for project.This project has resource management, scheduling and BOQ with rates.

\section{CONCLUSION}

* Project Management Model is an effective tool that helps to achieve optimized cost and time duration.

* The main reason for delay in project 2 is using fewer resources and not increasing the resources using same manpower for all the works which leads to more poor quality of work, the output is zero.

* The results of this study can be of immense help to the practitioners (clients, contractors and consultants) and academicians.

* The practitioners can better understand the dynamics of project management and make efforts to reduce the incidences of delays.

* This project management model will also serve as a baseline for future projects.

\section{REFERENCES}

1. V.Subburaj. NVN.Nampoothiri and M.Shanmuga sundram (2018) "A Project management model for an experimental construction management project” IJCIET-09-11-156. ISSN Print:0976-6308.

2. Aibinu, A. A., and Odeyinka, H. A. (2006). "Construction delays and their causative factors in Nigeria". J. Constr. Eng. and Mgmt., (ASCE), 132(7), 667-677.

3. Alwi, S., and Hampson, K. (2003). "Identifying the important causes of delays in building construction projects". The 9th East Asia-Pacific conference on structural eng. and constr., Bali, Indonesia.

4. Al-Khalil, M. I. and Al-Ghafly, M .A. (1999), 'Delay in public utility projects in Saudi Arabia'. International Journal of Project Management, 17(2)101-106.

5. Aibinu AA, Jagboro GO. The effects of construction delays onproject delivery in Nigerian construction industry. Int $\mathrm{J}$ ProjectManage 2002;20:593-9.
6. Ajanlekoko JO. Controlling cost in the const industry. LagosQS Digest, Lagos 1987;1(1):8-12.

7. Ashwini Arun Salunkhe1, Rahul S. Patil, Statistical Methods for Construction Delay Analysis

8. Chan DWM, Kumaraswamy MM. A comparative study of causes oftime overruns in Hong Kong construction projects. Int J ProjectManage 1997;15(1):55-63.

9. Chan DWM, Kumaraswamy MM. Compressing construction durations:lessons learned from Hong Kong building projects. Int $\mathbf{J}$ ProjectManage 2002;20:23-35.

10. Sambasivan, M. and Soon, Y.W. (2007), Causes and Effects of Delays in Malaysia Construction Industry. International Journal of Project Management, 25:517-526.

11. IOSR Journal of Mechanical and Civil Engineering (IOSR-JMCE)Odeyinka HA, Yusif A. The causes and effects of construction delayson completion cost of housing project in Nigeria. J Financial Manage Property Construction 1997;2(3):31-44.

12. Ogunlana SO, Promkuntong $K$. Construction delays in a fast growingeconomy: comparing Thailand with other economies. Int $\mathbf{J}$ ProjectManage 1996;14(1):37-45

\section{AUTHORS PROFILE}

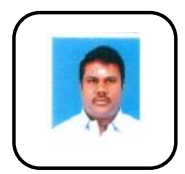

V .Subburaj, is currently working as Assistant Professor in Department of Civil Engineering, PSNACET, Dindigul, Tamilnadu, India.

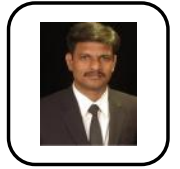

Ramesh Babu Chokkalingam completed his $\mathrm{Ph} . \mathrm{D}$. from IIT Chennai in 2008. He has more than 10 years of experience in teaching and research.His areas of research includes pervious concrete, geopolymer concrete, and high volume flyash concrete.

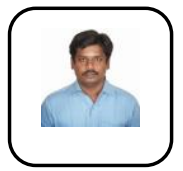

M.Shanmugasundaram completed his Ph.D in 2014.He has $30+$ international research publications to his credits. He has 3 years of industrial experience and 10 years of teaching experience. His recent research interests include sustainable materials and polymer concrete. 
Table 1 Bill of Quantities with rates for M/s Chellammal Residency

\begin{tabular}{|c|c|c|c|c|c|}
\hline S.No & Description of work & Unit & Qty & $\begin{array}{c}\text { Rate/Unit } \\
\text { (Rs) }\end{array}$ & $\begin{array}{l}\text { Amount } \\
\text { (Rs) }\end{array}$ \\
\hline & Concrete works and Brick works & & & & \\
\hline & Substructures & & & & \\
\hline 1 & $\begin{array}{l}\text { Excavation work for basement and } \\
\text { foundation }\end{array}$ & C.ft & 35703 & 8 & $2,85,624$ \\
\hline 2 & Refilling work & C.ft & 16000 & 6 & 96,000 \\
\hline 3 & PCC Concreting for footing & C.ft & 1130 & 116 & $1,31,080$ \\
\hline \multirow[t]{2}{*}{4} & Retaining wall construction & C.ft & 5798 & 135 & $7,82,730$ \\
\hline & Ground Floor & & & & \\
\hline 5 & $\begin{array}{lccr}\begin{array}{l}\text { Concreting } \\
\text { columns, } \\
\text { sunshades. }\end{array} & \begin{array}{l}\text { work } \\
\text { roof, }\end{array} & \begin{array}{c}\text { of } \\
\text { lintels }\end{array} & \begin{array}{r}\text { beams, } \\
\text { and }\end{array} \\
\end{array}$ & C.ft & 3550 & 252 & $8,94,600$ \\
\hline \multirow[t]{2}{*}{6} & Brick Masonry & C.ft & 2600 & 112 & $2,91,200$ \\
\hline & First Floor & & & & \\
\hline 7 & $\begin{array}{lccr}\begin{array}{l}\text { Concreting } \\
\text { columns, } \\
\text { sunshades. }\end{array} & \begin{array}{l}\text { work } \\
\text { roof, }\end{array} & \begin{array}{c}\text { of } \\
\text { lintels }\end{array} & \begin{array}{r}\text { beams, } \\
\text { and }\end{array} \\
\end{array}$ & C.ft & 2350 & 298 & $7,00,300$ \\
\hline \multirow[t]{2}{*}{8} & Brick Masonry & C.ft & 2955 & 112 & $3,30,960$ \\
\hline & Second Floor & & & & \\
\hline 9 & $\begin{array}{lccr}\begin{array}{l}\text { Concreting } \\
\text { columns, } \\
\text { sunshades. }\end{array} & \begin{array}{c}\text { work } \\
\text { roof, }\end{array} & \begin{array}{c}\text { of } \\
\text { lintels }\end{array} & \begin{array}{r}\text { beams, } \\
\text { and }\end{array} \\
\end{array}$ & C.ft & 2350 & 298 & $7,00,300$ \\
\hline \multirow[t]{2}{*}{10} & Brick Masonry & C.ft & 2955 & 112 & $3,30,960$ \\
\hline & Third Floor & & & & \\
\hline 11 & $\begin{array}{lccr}\begin{array}{l}\text { Concreting } \\
\text { columns, } \\
\text { sunshades. }\end{array} & \begin{array}{l}\text { work } \\
\text { roof, }\end{array} & \begin{array}{c}\text { of } \\
\text { lintels beams, }\end{array} & \begin{array}{r}\text { and } \\
\text { and }\end{array} \\
\end{array}$ & C.ft & 2350 & 298 & $7,00,300$ \\
\hline 12 & Brick Masonry & C.ft & 2955 & 112 & $3,30,960$ \\
\hline
\end{tabular}

Table 2. Resource Allocation using Software

Total

$\mathrm{g}$ HD1061 Center line marking

P HD1056 Surveyüng and Eoundiry marking

Q. Barbender

g HD1581

H HD1636

B HD2081

HD2071

$\mathrm{g}$ HD2061

$2 \mathrm{HD2046}$

요 HD2D31

2 HD1881

HD1871

곡 HD1846

을 HD1846

2 HD1431

$2 \mathrm{HD} 1416$

2 HD1831

HD1451

HD1441

공 HD14D1

용 HD14D1

HD1376

HD1326

HD1316

HD1296

HD1246

욤 HD1221

HD1211

P HD1206

HD11a1

20 HD1161

HD1146

HD1096

B HDidre

Concret

ge HD2176

영 HD1891

욤 HD1461

Column reirrforcenent for kitchen and s

itchen platform

Pacing of rods

Beam and roof slab barbending

Column concreting abowe lintel

Lintel level shuttering and surshade we

Column reirrforcement upto li rntel level

Pacing of rocts

Peam and roof slab barbending

Lintel lewel shuttering and surshade wr

column concreting aboure lintel

Column concreting abowe lintel

Lintel I evel shuttering and surshade wo

Column reirforcernent upto li mtel level

P1acing of rods

Beam and roof slab barbending

Column reirforcernent upto lintel level

Column concreting above lintel

kitchen eooking platform

P1acing of rods

Beam and roof slab barbending

Lintel I ewel shuttering and surshade we

Column reirrforcement upto lintel

Placing and tying of rod

floor slab barbending works

Ramp work

einforcerment

Retaining wall and column reinforcement

Peam and slab reinforcement

Footing erection and col umn fixing

Bar bending works for footing and colur

Mixer

Concreting

Concreting

\section{QT-Mar-1E}

OT-Mar-18

OS-Mar-18

OT-Mar-18

Oe-Mar-18

$27-5 e p-13$

$05-\operatorname{sep}-18$

27 -Aug- 18

27-Aug-1B

23-Aug-1B

OT-Aug-1B

30 Jul-1a

21-Jul-1a

18-Jul-1a

21-Jul-1a

15-Jun-18

12-Jun-18

94-Jull-1a

25-Jun-18

15-Jun-18

2e-May-13

12-May-1s

05-Jun-18

21-May-18

12-M 12

OB-May-1B

28-Ape-18

18-Apr-18

04-Apr-18

12 -Apr-18

O8-Apr-18

28-Mar-13

15-Mar-18

oe-mar-18

28-May-18

$10-5 e p-18$

04-Aug-18

18

28-May-18
09-Mar-18

Q9-Mar-1a ae-Mar-19 28 -Sep-1a 19-Sep-1a $2 a-5 e p-19$ a日sep30-Aug-19 30-Aug-13 27-Aug-19 11-Aug-1B 03-Aug-1a 25-Jul-18 24-Jul-18 19-Jun-18 15-Jun-18 a7-Jul-18 20-Jun-19 20-Jun-19 02-Jun-18 15-May-18 ae-Jun-1B 25-May-18 10-Mar-18 11-11 11-ma a2-May-18 21-Apr-18 a7-Apr-18 12-Apr-19 a 7 -Apr-1B व (a) 17-Mar-19 12-Mar-1a 11-Sep-1B 11-Sep-13 04- Aug- 13 02-Jul-18 20-May-18

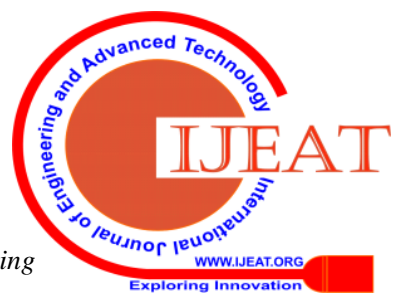


Impact of Construction Project Execution with and without Project Management Software

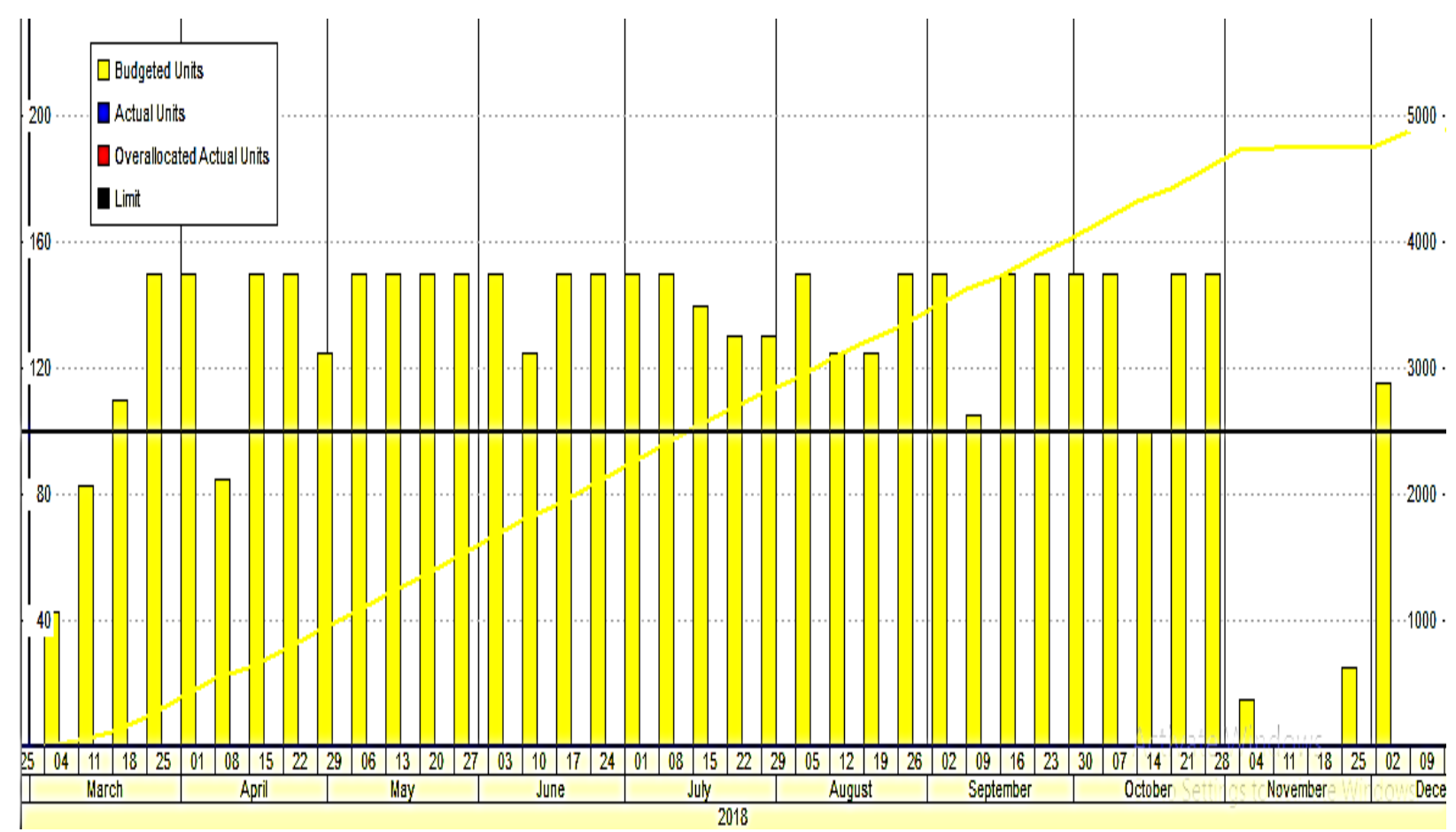

Fig. 1. Resource Levelling for Project Engineer

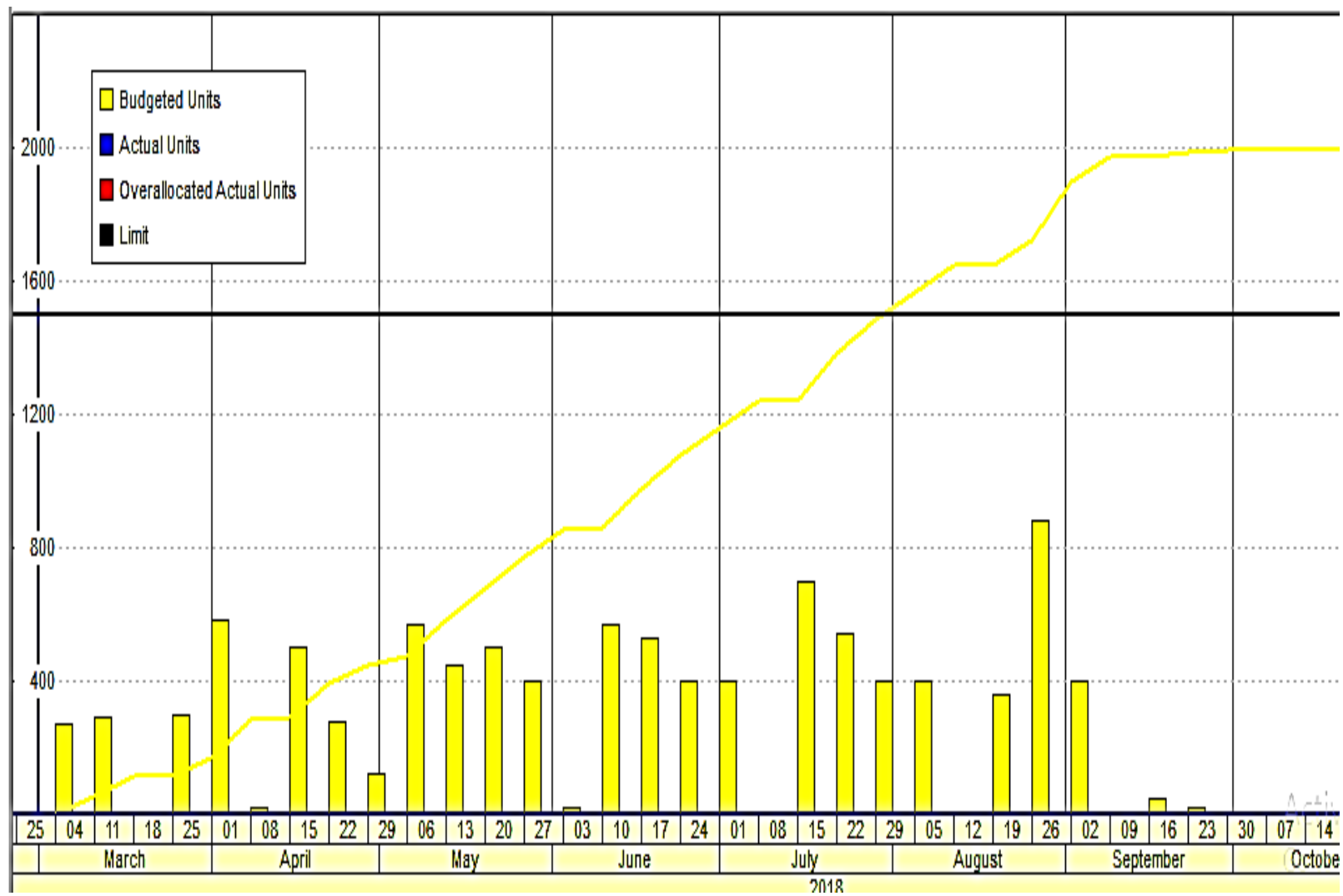

Fig. 2. Resource Levelling for Bar bender 
Table 3. MILESTONE ACTIVITIES FOR M/s Chellammal Residency

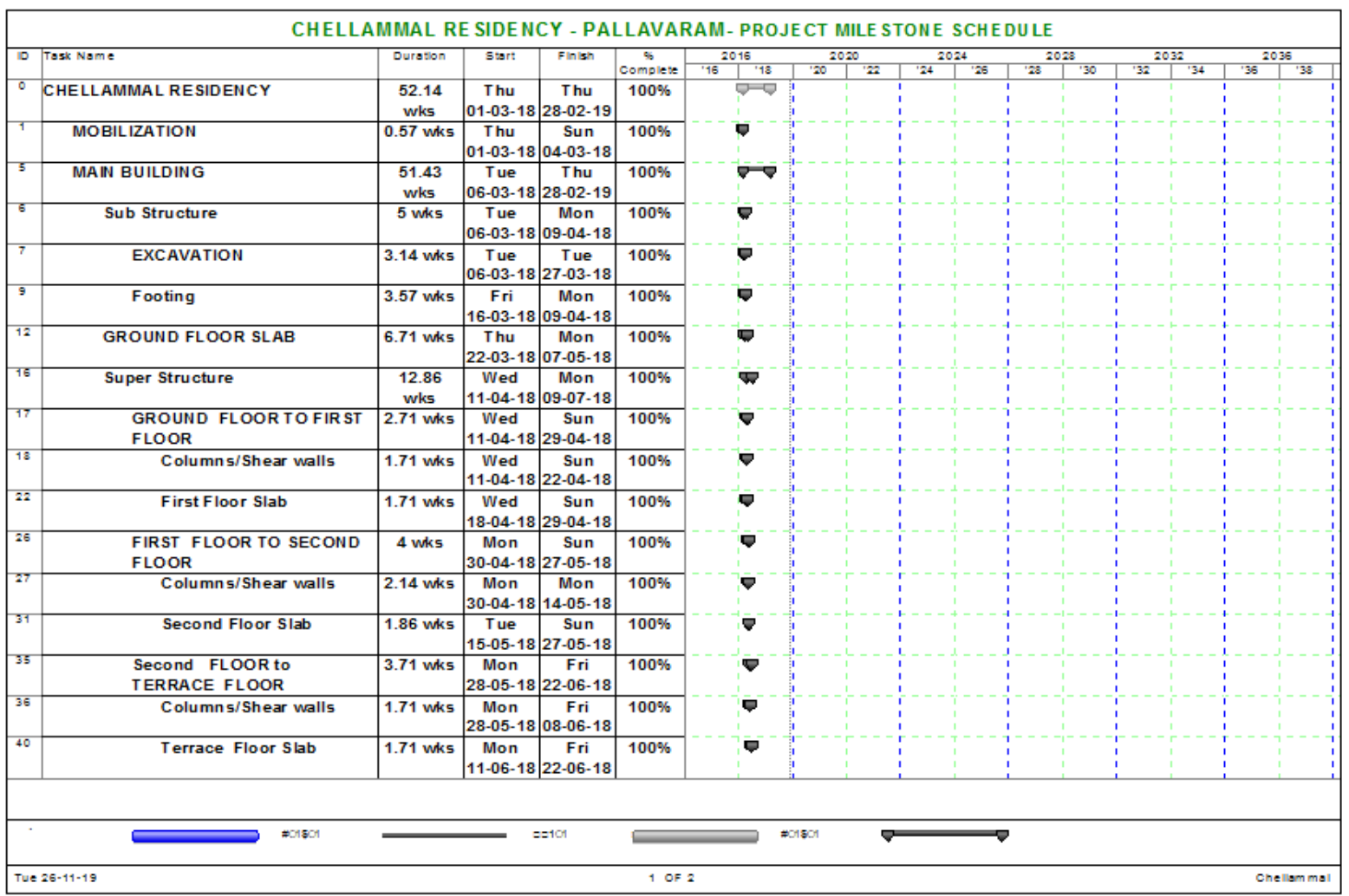

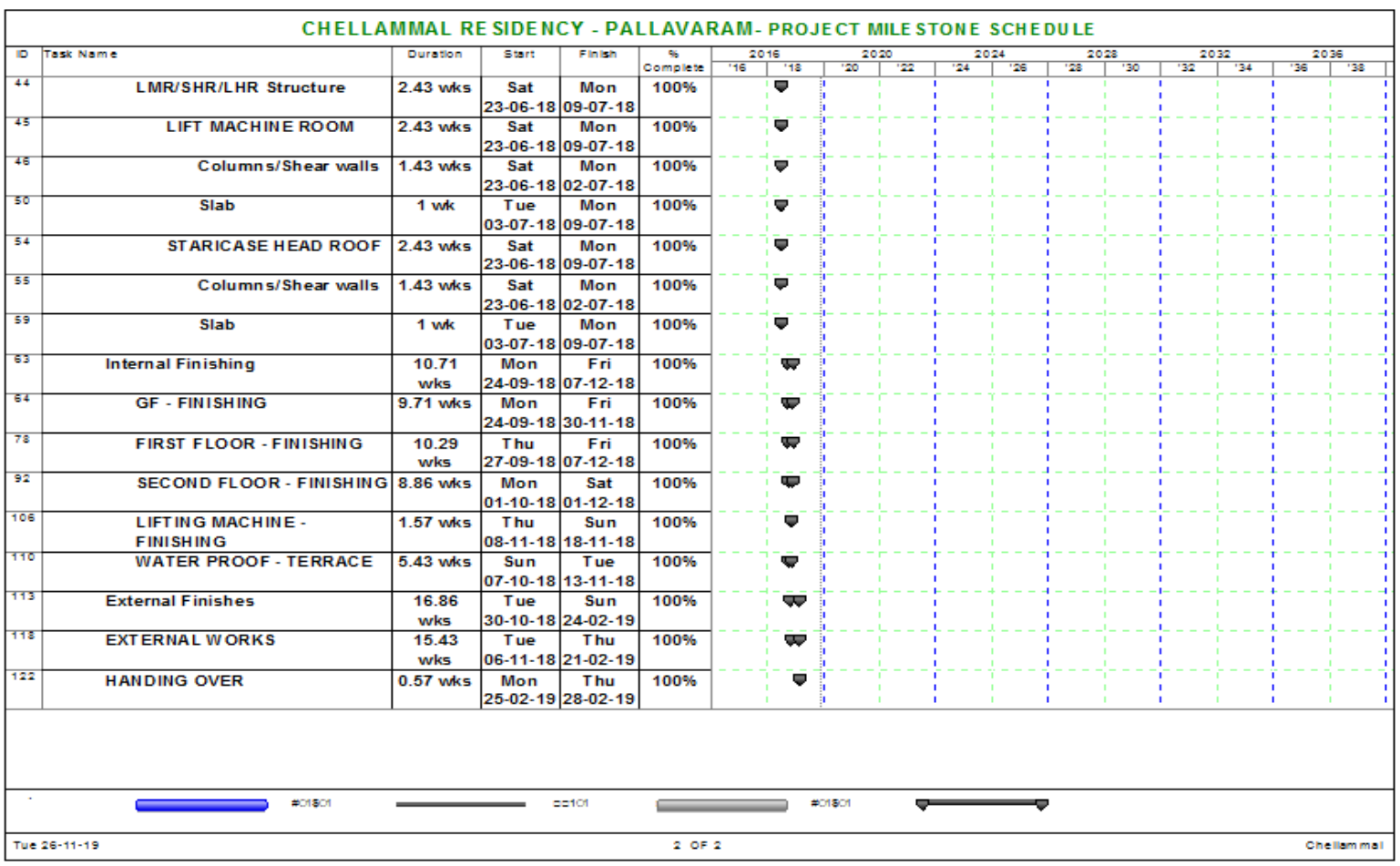


Impact of Construction Project Execution with and without Project Management Software

Table 4. Progress report on project $1 \& 2$

\begin{tabular}{|c|c|c|c|c|}
\hline & \multicolumn{2}{|c|}{$\begin{array}{c}\text { Chellammal Residency }-\mathrm{M} / \mathrm{s} \\
\text { Finetune Builders }\end{array}$} & \multicolumn{2}{|l|}{$\begin{array}{l}\text { Sumangali Apartments } \\
\text { - M/s Limra Builders }\end{array}$} \\
\hline Month & Progress & Review & Progress & Review \\
\hline Nov'14 & & & First meeting held between Contracor \& Client & \\
\hline Dec"14 & & & Document Photo copies verified & \\
\hline Jan'15 & & & Both Client \& Contractor accepted to start the work & \\
\hline Feb'15 & & & Problem in Survey No & \\
\hline Mar'15 & & & So Work not started & \\
\hline Apr'15 & & & Work not started & \\
\hline May'15 & & & $\begin{array}{c}\begin{array}{l}\text { Survey No problem sorted out so accepted to start the } \\
\text { work }\end{array}\end{array}$ & \\
\hline Jun'15 & & & Document preparation occurs & \\
\hline July'15 & & & Power Of Attorney signed & \\
\hline Aug'15 & & & Work not started & Due to \\
\hline Sept'15 & & & Work not started & Improper \\
\hline Oct'15 & & & Work not started & planning \\
\hline Nov'15 & & & Work not started & $\begin{array}{c}\text { from builder } \\
\text { work not } \\
\text { started. }\end{array}$ \\
\hline Dec'15 & & & Natural Disaster - Flood Came & No planning, \\
\hline Jan'16 & & & So Work not started & scheduling, \\
\hline Feb'16 & & & Work not started & resource \\
\hline Mar'16 & & & Work not started & management \\
\hline Apr'16 & & & Got the approval & and tool not \\
\hline May'16 & & & Frame work progress & \\
\hline Jun'16 & & & Frame work progress & \\
\hline July'16 & & & Frame work progress & \\
\hline Aug'16 & & & 2 Floors Frame work completed & \\
\hline Sept'16 & & & Work Stopped & Due to poor \\
\hline Oct'16 & & & Work Stopped & quality \\
\hline Nov'16 & & $\begin{array}{l}\text { Scheduling } \\
\text { for the } \\
\text { project is } \\
\text { done with } \\
\text { Primavera } \\
\text { and MS P. } \\
\text { For effective } \\
\text { scheduling } \\
\text { process the } \\
\text { resources are } \\
\text { allocated } \\
\text { properly } \\
\text { according to }\end{array}$ & Work Stopped & $\begin{array}{l}\text { engineer, } \\
\text { work } \\
\text { stopped, } \\
\text { Also Builder } \\
\text { is not a } \\
\text { technically } \\
\text { qualified } \\
\text { person } \\
\text { having less } \\
\text { knowledge } \\
\text { on execution } \\
\text { and not to } \\
\text { accept new }\end{array}$ \\
\hline Dec'16 & & & Work Stopped & technology \\
\hline Jan'17 & & availability. & Work Stopped & makes more \\
\hline Feb'17 & & & Work Stopped & \\
\hline Mar'17 & & & Work Stopped & \\
\hline Apr'17 & & & & \\
\hline May'17 & & & Work Stopped & \\
\hline Jun'17 & & & Frame work progress & $\begin{array}{c}\text { Work started } \\
\text { after } 9 \\
\text { months }\end{array}$ \\
\hline July'17 & & & Frame work progress & \\
\hline Aug'17 & & & Frame work progress & \\
\hline Sept'17 & & & Final Floor Frame work completed & \\
\hline Oct'17 & & & Block work in progress & \\
\hline
\end{tabular}




\begin{tabular}{|c|c|c|c|}
\hline Nov'17 & Project started & Block work in progress & \\
\hline Dec'17 & $\begin{array}{l}\text { Plan - layout } \\
\text { prepared using } \\
\text { software. }\end{array}$ & Block work in progress & \\
\hline Jan'18 & $\begin{array}{l}\text { PPM- Schedule } \\
\text { prepared using } \\
\text { software. }\end{array}$ & Block work / Plastering work in progress & \\
\hline Feb'18 & $\begin{array}{c}\text { BOQ \& } \\
\text { approval } \\
\text { processed. }\end{array}$ & Block work / Plastering work in progress & \\
\hline Mar'18 & $\begin{array}{c}\text { Foundation } \\
\text { started }\end{array}$ & Block work / Plastering work in progress & \\
\hline Apr'18 & $\begin{array}{l}\text { Foundation } \\
\text { completed as } \\
\text { per schedule }\end{array}$ & Block work / Plastering work completed. & \\
\hline May'18 & $\begin{array}{l}\text { Ground floor } \\
\text { Frame started }\end{array}$ & Electrical / Plumbing works in progress & \\
\hline Jun'18 & $\begin{array}{l}\text { Ground floor } \\
\quad \text { Frame } \\
\text { completed as } \\
\text { per schedule. }\end{array}$ & Electrical / Plumbing works erection works completed. & \\
\hline Jun'18 & $\begin{array}{c}\text { First floor } \\
\text { Frame started }\end{array}$ & Tile flooring started & \multirow{6}{*}{\begin{tabular}{|c|} 
Due to less \\
awareness \\
and poor \\
knowledge \\
about the \\
field it is \\
very difficult \\
for the \\
builder to get \\
succeed in \\
project
\end{tabular}} \\
\hline July'18 & $\begin{array}{l}\text { First floor } \\
\text { Frame } \\
\text { completed }\end{array}$ & Tile flooring completed. & \\
\hline Aug'18 & $\begin{array}{l}\text { Second floor } \\
\text { Frame started }\end{array}$ & Putty work completed. & \\
\hline Sept'18 & $\begin{array}{l}\text { Second floor } \\
\text { Frame } \\
\text { completed as } \\
\text { per PPM }\end{array}$ & Doors \& Windows - Frame fixing work in progress & \\
\hline Oct'18 & $\begin{array}{c}\text { Terrace/ Gr Flr } \\
- \\
\text { Finishing/MEP } \\
\text { work } \\
\text { completed }\end{array}$ & Doors \& Windows - Shutter fixing work in progress & \\
\hline Nov'18 & $\begin{array}{c}\text { FF - } \\
\text { Finishing/MEP } \\
\text { work } \\
\text { completed as } \\
\text { per PPM } \\
\end{array}$ & $\begin{array}{c}\text { Doors \& Windows - Frame / Shutter fixing work } \\
\text { completed }\end{array}$ & \\
\hline Dec'18 & $\begin{array}{c}\text { SF - } \\
\text { Finishing/MEP } \\
\text { work } \\
\text { completed as } \\
\text { per PPM } \\
\end{array}$ & Work stopped & \multirow{3}{*}{$\begin{array}{l}\text { Due to poor } \\
\text { performance } \\
\text {, Builder got } \\
\text { more stress } \\
\text { and takes } \\
\text { time for him } \\
\text { to recover. }\end{array}$} \\
\hline Jan'19 & $\begin{array}{l}\text { Snag / Final } \\
\text { works } \\
\text { progressed as } \\
\text { per PPM }\end{array}$ & Work stopped & \\
\hline Feb'19 & $\begin{array}{l}\text { Snag / Final } \\
\text { other works } \\
\text { completed as } \\
\text { per PPM }\end{array}$ & Work stopped & \\
\hline
\end{tabular}


Impact of Construction Project Execution with and without Project Management Software

\begin{tabular}{|c|c|c|c|c|}
\hline Mar'19 & $\begin{array}{c}\text { All works } \\
\text { including lift } \\
\text { work } \\
\text { completed. }\end{array}$ & & Work stopped \\
\hline Apr'19 & & & Compound wall work completed. & $\begin{array}{c}\text { Budgeting } \\
\text { estimation } \\
\text { not done by } \\
\text { the builder }\end{array}$ \\
\hline May'19 & & & Painting work in progress. & \\
\hline Jun'19 & & Balance work yet to complete & \\
\hline Jul'19 & & & Balance work yet to complete \\
\hline Aug'19 & & MEP \& Grill works & \\
\hline Sept'19 & & & Painting works \\
\hline
\end{tabular}

